UNIVERSIDADE DE SÃO PAULO

FACULDADE DE ECONOMIA, ADMINISTRAÇÃO E CONTABILIDADE DEPARTAMENTO DE ADMINISTRAÇÃO

PROGRAMA DE PÓS-GRADUAÇÃO EM ADMINISTRAÇÃO

Área de Métodos Quantitativos e Informática

UM MÉTODO DE ANÁLISE E PREVISÃO DE SUCESSÕES

CRONOLÓGICAS UNIDIMENSIONAIS

LINEARES E NÃO-LINEARES

Fabiano Guasti Lima

Orientador: Prof. Dr. José de Oliveira Siqueira 
FABIANO GUASTI LIMA

\title{
UM MÉTODO DE ANÁLISE E PREVISÃO DE SUCESSÕES CRONOLÓGICAS UNIDIMENSIONAIS \\ LINEARES E NÃO-LINEARES
}

\author{
Tese apresentada ao Departamento de \\ Administração da Faculdade de Economia, \\ Administração e Contabilidade da \\ Universidade de São Paulo, como requisito \\ parcial para a obtenção do título de Doutor em \\ Administração.
}

Orientador: Prof. Dr. José de Oliveira Siqueira 


\section{DEDICATÓRIA}

Aos meus avós Pedro Lima e Olga Guasti Lima, que mesmo não estando presentes, deram origem à minha família com amor, carinho $e$ dedicação. 


\section{AGRADECIMENTOS}

- Primeiramente devo agradecer a DEUS, que me proporcionou a graça de viver, aprender e crescer. E a NOSSA SENHORA APARECIDA, a eterna gratidão da saúde concedida por mais este trabalho.

- $\quad$ A minha mãe, Profa. Ms. Zulmira Guasti Lima, que sempre me dedicou amor e com quem aprendi a ter orgulho e continuar acreditando.

- A minha esposa, Profa. Ms. Milena Moscardini Nabelice Guasti Lima, pela paciência, apoio e carinho, para que juntos pudéssemos provar o sabor desta conquista.

- Ao Prof. Dr. José de Oliveira Siqueira, meu orientador, agradeço a grande e positiva influência que efetivamente exerceu em minha formação acadêmica e pela brilhante contribuição neste trabalho.

- Ao Uni-FACEF - Centro Universitário de Franca, pelo apoio financeiro durante o período de elaboração desta obra.

- E são tantas as pessoas que, das mais diferentes maneiras, participaram desta história. A elas, meu mais sincero agradecimento. 


\section{RESUMO}

LIMA, F. G. UM MÉTODO DE ANÁLISE E PREVISÃo DE SUCESSÕES CRONOLÓGICAS UNIDIMENSIONAIS LINEARES E NÃO-LINEARES . 2004. 227f. Tese (Doutorado). Faculdade de Administração, Economia e Contabilidade, Universidade de São Paulo, São Paulo, 2004.

O objetivo principal deste trabalho é o de explorar a possibilidade de usar uma metodologia capaz de decompor uma série temporal via ondaletas, conjuntamente com os modelos econométricos e de redes neurais já existentes de previsão e comparar a qualidade de previsões obtidas para sucessões cronológicas lineares e não-lineares simuladas. A proposta é alcançada, principalmente, pela elaboração de um fluxograma para tratamento das previsões de sucessões cronológicas para colocar um rigor quantitativo mais adequado. O diferencial deste trabalho está na realização das previsões dentro das subséries decompostas por uma ondaleta em até dois níveis, obtendo-se a previsão da série original via reconstrução da série, para modelos construídos por processos geradores de dados de sucessões cronológicas lineares e não-lineares. Foram simuladas sucessões cronológicas de um processo ARIMAGARCH, um processo ARIMA, um processo bilinear e um movimento browniano. O trabalho principal constituiu-se na elaboração da fase de pré-processamento e das previsões estáticas em separado para cada uma das sub-séries encontradas, sendo feitas para 10 e 200 observações futuras. Além das previsões pontuais foi verificado, também, o envelopamento dos dados, que consiste em comparar o modelo de previsão através de um intervalo de confiança para os valores previstos em mil séries simuladas pela mesma semente. Os resultados apontaram que, para um modelo ARIMA(1,0,0)-GARCH(1,1), pode-se observar que o pré-processamento pela ondaleta foi melhor para apenas uma etapa de separação de altas e baixas freqüências, tanto pela correlação quanto pelos critérios do TIC sendo este reduzido, e pelo MAPE menor, para as previsões de curto prazo. Já para os modelos de redes neurais, uma diferença importante que deve ser ressaltada entre as redes neurais recorrentes e as redes com algoritmo de retropropagação é a capacidade de previsão das redes recorrentes para dados não-lineares com dois níveis de pré-processamento e para previsões de curto prazo. Todavia, já para o critério do envelopamento, os melhores resultados foram para as redes recorrentes na previsão do processo ARIMA-GARCH e bilinear e pré-processamento com um nível. Todos os dados também foram comparados com as previsões feitas sem préprocessamento, as quais se mostraram impróprias com MAPE perto de 100\% para previsões de longo prazo. Também foram verificadas, neste trabalho, as alterações que a mudança da escolha de uma ondaleta por outra, poderia impactar nos resultados das previsões futuras. Constatou-se que a troca por formas de onda no pré-processamento que se pareçam mais visualmente com a forma dos dados da série aumenta as medidas de acurácia, deixando evidências de que possa haver melhoras nos resultados. $\mathrm{Na}$ análise prática, para o IBOVESPA, os resultados não foram satisfatórios, visto que os melhores resultados ficam para redes recorrentes com um nível de pré-processamento. Outrossim, da análise deste trabalho, emerge o significado dado ao fluxograma implementado para as previsões, o papel das previsões em separado por ondaletas como redutores dos erros nos processos estocásticos e da implementação das bandas de previsões para redes recorrentes para sucessões cronológicas lineares e não-lineares.

PALAVRAS-CHAVE: ARIMA; envelopamento; GARCH; ondaletas; previsão; redes neurais recorrentes; sucessões cronológicas. 


\begin{abstract}
LIMA, F. G. A METHOD OF ANALYSIS AND FORECASTING IN LINEAR AND NONLINEAR UNIDIMENSIONAL TIME SERIES. 2004. 227f. Thesis (Doctoral). Faculdade de Administração, Economia e Contabilidade, Universidade de São Paulo, São Paulo, 2004.
\end{abstract}

The main goal of this work is to explorer the possibility of using a methodology capable to decompose a time series through wavelets, jointly with the econometrics and neural network models of forecast already existent and to compare the forecast quality obtained for simulated linear and nonlinear data. The proposal was reached mainly by the elaboration of a flowchart for time series forecasts treatment in order to achieve a more appropriate quantitative precision. The forecasts accomplishment inside the sub-series decomposed by an wavelet in up two levels, and being obtained the forecast of the original series through reconstruction of the series for models built by generating processes of linear and nonlinear time series is the core of this work. We simulated series of an ARIMA-GARCH process, ARIMA process, bilinear process and a brownian movement. The elaboration of the pre-processing phase and the static forecasts in separate for each on the found sub-series constitute the main work, being done for 10 and 200 future observations. Besides the punctual forecasts it was also verified the data enveloping, which consist of comparing the forecast model through a confidence interval for the values foreseen in a 200 simulated series by the same seed. The results indicates that for a ARIMA-GARCH model it can be observed that the pre-processing for the wavelet was better for just one separation stage of high and low frequencies, as much for correlation as for the TIC criteria, being this reduced, and for smaller MAPE for the short period forecasts. But for the neural network models an important difference that should be emphasize between the recurrent neural network and the backpropagation neural network algorithms is the forecast ability of the recurrent neural network for nonlinear data with two pre-processing levels and for short period forecasts. Though, for the enveloping criterion, the best results were obtained for recurrent neural networks in the forecast of the ARIMAGARCH and bilinear process with pre-processing at one level. All data were also compared with the forecasts done without pre-processing, which were shown in appropriate with MAPE close to $100 \%$ for long period forecasts. It was also checked in this work the modification that the change in the choice at a wavelet from other was able to impact in the future forecasts results. It was verified that the change in the wave form in the pre-processing for another wavelet visually similar to the data form increases the precision measures indicating that we can have improvements in the results. The results were not satisfactory in the practical analysis for IBOVESPA, because the best results are for recurrent neural networks with one pre-processing level. Likewise, from this work analysis the importance given to the flowchart implemented for the forecasts, the role of the forecasts in separate for wavelets as reduces of the errors in the stochastic processes and the implementation of the forecasts bands for recurrent neural networks for linear and nonlinear time series emerges.

KEY WORDS: ARIMA, enveloping, GARCH, wavelets, forecasting, recurrent neural networks, time series. 